\title{
ANALISIS SEKTOR BASIS DAN KONTRIBUSI SEKTOR PERTANIAN TERHADAP PRODUK DOMESTIK REGIONAL BRUTO DI KABUPATEN DAIRI
}

\author{
Rahmanta \\ Staf Pengajar Program Studi Agribisnis Fakultas Pertanian \\ Universitas Sumatera Utara, Jl. Dr. A Sofyan No.3, Medan Baru, \\ Kota Medan, Sumatera Utara 20155 \\ Telp.(061) 8213236. Email: rahmantaginting@yahoo.com
}

\begin{abstract}
The agriculture sector is one sector of the economy given a priority in regional development, it's because most of the population dependent on the sector and a source of income for the majority of the population, thus it's no wrong if the agriculture sector serves as a support the regional development. The agriculture sector in the district Dairi consists of food crops and horticulture, plantation, animal husbandry, foresty, and fishery. Therefore, the purpose of this study is to analyze the basis sector and agriculture sector contribution to the gross regional domestic product in the district Dairi. This study uses secondary data sourced form of time series data from 2009 - 2013. The analysis model is a Location Quotient (LQ) and sector contribution to gross regional domestic product in district Dairi. The result showed that the agriculture sector and the services is a basis sector or have a high role in a local economy. It is characterized by $L Q$ is greather than one, while other sectors are non basis sector because it has a LQ value smaller than one. In 2013, the agriculture sector provides the largest contribution in gross regional domestic product structure in the district Dairi is $58,47 \%$.
\end{abstract}

Keywords: basis sector, agriculture sector contribution, gross regional domestic product, and location quotient 


\section{PENDAHULUAN}

abupaten Dairi mempunyai Luas 192.780 ha atau sekitar 2,69 persen dari luas Propinsi Sumatera Utara yaitu 7.160.000 ha. Kabupaten Dairi terletak sebelah Barat Daya Propinsi Sumatera Utara. Sebagian besar Kabupaten Dairi terdiri dari dataran tinggi dan berbukit-bukit. Kabupaten Dairi terletak antara 98000'-98030' BT dan 2015'00"-3000'00" LU. Sebagian besar tanahnya berupa gunung-gunung dan bukit-bukit dengan kemiringan bervariasi sehingga terjadi iklim hujan sub tropis. Kota Sidikalang adalah ibukota Kabupaten Dairi.

Pada umumnya daerah Kabupaten Dairi adalah potensi pertanian yang cukup luas dengan hasil yang besar. Sehingga mata pencarian penduduk yang terutama adalah bertani padi, palawija, tanaman tahunan dan komoditas ekspor antara lain: (a) Tanaman bahan makanan adalah padi, jagung, ketela rambat, ketela pohon, kacang tanah, kacang kedelai dan kacang hijau. (b) Tanaman sayur-sayuran adalah cabe, kentang,tomat, buncis, terung, bayam dan sayur-sayuran lainnya sangat baik di Kabupaten Dairi. Sedangkan tanaman bawang merah dan bawang putih di Kecamatan Sumbul yakni didesa Silalahi II dan desa Paropo yang terletak di pinggiran Danau Toba. (c) Tanaman komoditas ekspor seperti kopi, kelapa, kemenyan, cengkeh, tembakau, jahe, dan kemiri serta kulit manis dan nilam. Tanaman tahunan sangat baik diusahakan karena mempunyai hasil yang cukup besar jumlahnya, sehingga dapat mempengaruhi perekonomian masyarakat Kabupaten Dairi. Mata pencaharian tambahan juga diperoleh dari hasil hutan seperti kayu, dan komoditi lainnya.

Pembangunan merupakan suatu proses mulitidimensi yang mencerminkan perubahan stuktur masyarakat secara keseluruhan baik itu stuktur nasional, sikap masyarakat dan kelembagaan nasional. Perubahan tersebut bertujuan untuk mendorong pertumbuhan ekonomi, mengurangi ketimpangan pendapatan dan memberantas kemiskinan sehingga diharapkan terwujudnya kondisi kehidupan yang lebih baik secara material maupun spiritual (Todaro, 2000).

Salah satu indikator ekonomi makro yang berperan dalam membuat perencanaan kebijaksanaan dalam pembangunan daerah, menentukan arah pembangunan serta mengevaluasi hasil pembangunan suatu wilayah adalah Produk Domestik Regional Bruto. PDRB dapat dijadikan sebagai 
indikator laju pertumbuhan ekonomi sektoral agar dapat diketahui sektorsektor mana saja yang menyebabkan perubahan pada pertumbuhan ekonomi. Besar kecilnya PDRB yang dapat dihasilkan oleh suatu wilayah/daerah tergantung oleh besarnya sumberdaya alam yang telah dimanfaatkan, jumlah dan mutu sumberdaya manusia, kebijaksanaan pemerintah, letak geografis serta tersedianya sarana dan prasarana di wilayah tersebut. Oleh karena itu, diharapkan setiap pemerintah daerah harus mengetahui sektor basis yang menjadi prioritas dalam peningkatan pembangunan dan seberapa besar kontribusi sektor perekonomian terhadap pembangunan daerah.

Berdasarkan latar belakang di atas, maka yang menjadi tujuan penelitian ini adalah: (1) Untuk menganalisis sektor basis atau unggulan dalam perekonomian kabupaten Dairi; (2) Untuk menganalisis kontribusi sektor pertanian terhadap perekonomian kabupaten Dairi.

Teori ekonomi basis menyatakan bahwa faktor penentu utama pertumbuhan ekonomi suatu daerah adalah berhubungan langsung dengan permintaan barang dan jasa dari suatu daerah. Proses produksi di sektor pertanian dan industri suatu daerah yang menggunakan sumber daya produksi lokal, termasuk tenaga kerja dan bahan baku, dan outputnya diekspor akan menghasilkan pertumbuhan ekonomi, peningkatan pendapatan per kapita, dan penciptaan peluang kerja di daerah tersebut (Tambunan, 2001).

Dalam model basis ekonomi dinyatakan bahwa faktor penentu utama pertumbuhan ekonomi suatu daerah adalah keuntungan kompetitif yang berhubungan langsung dengan permintaan barang dan jasa dari luar daerah. Berdasarkan teori ini perekonomian suatu wilayah dibagi menjadi dua yaitu sektor basis dan sektor non basis. Sektor basis adalah sektor yang menjadi tulang punggung perekonomian daerah karena mempunyai keuntungan kompetitif yang cukup tinggi, sehingga mampu mengekspor barang dan jasa ke luar batas-batas perekonomian wilayah yang bersangkutan. Sedangkan sektor non basis merupakan kegiatan-kegiatan yang menyediakan barang dan jasa untuk memenuhi kebutuhan orangorang yang bertempat tinggal di dalam batas-batas perekonomian wilayah tersebut. Sektor non basis ini berfungsi sebagai sektor penunjang sektor basis atau service industries (Sjafrizal, 2008).

QE Journal |Vol.04 - No.02 June 2015 - 114 
Kuosien lokasi (Location Quotient) atau disingkat LQ adalah perbandingan dengan besarnya peranan suatu sektor di suatu daerah terhadap besarnya peranan sektor tersebut secara nasional. Analisis LQ memang sangat sederhana sehingga apabila digunakan dalam bentuk one shot analysis, manfaatnya juga tidak begitu besar yaitu hanya melihat nilai LQ berada diatas 1 atau tidak. Analisis LQ bisa dibuat menarik apabila dilakukan dalam bentuk time-series/trend, artinya dianalisis dalam beberapa kurun waktu tertentu (Tarigan, 2005).

Metode ini berguna untuk menentukan sektor basis/unggulan dan sektor non basis/non unggulan dengan cara menghitung perbandingan antara pendapatan di sektor i pada daerah bawah terhadap pendapatan total semua sektor di daerah bawah dengan pendapatan di sektor i pada daerah atas terhadap pendapatan total semua sektor di daerah atasnya. Daerah bawah dan daerah atas yang dimaksud adalah daerah administratif.

Metode LQ berguna untuk menentukan sektor pertanian di setiap kabupaten merupakan sektor unggulan atau sektor non unggulan. Selanjutnya, merumuskan untuk memprioritaskan kabupaten yang sektor pertanian adalah sektor unggulan dan yang sangat potensial untuk dikembangkan sehingga pada akhirnya akan menciptakan pertumbuhan ekonomi daerah tersebut.

Untuk menganalisis ekonomi suatu daerah, salah satu teknik yang lazim adalah LQ (Location Quotient). Pada LQ dapat digunakan untuk mengetahui seberapa besar tingkat spesialisasi sektor-sektor basis atau unggulan. Dalam teknik LQ berbagai peubah (faktor) dapat digunakan sebagai indikator pertumbuhan wilayah, misalnya kesempatan kerja dan Produk Domestik Regional Bruto (PDRB).

Nurfatimah (2013) melakukan studi tentang Analisis Potensi Pertumbuhan Ekonomi Kabupaten/Kota di Provinsi Bali, menggunakan metode Location Quotient (LQ), Sift Share dan Gravitasi. Hasil studi menunjukkan terjadi penyebaran sektor-sektor ekonomi yang basis di Provinsi Bali dan pemerataan pembangunan daerah di Bali. Pembangunan di Bali tidak dikhususkan untuk satu sektor di setiap kabupaten/kota tetapi terbagi-bagi untuk saling memenuhi kebutuhan tiap-tiap daerah. Hasil dari analisis gravitasi dengan nilai indeks terbesar menunjukkan keterkaitan atau daya tarik menarik potensi ekonomi antara Kota Denpasar dengan kabupaten 
lain di sekitarnya paling kuat adalah pertama dengan Kabupaten Klungkung, kedua interaksi dengan Kabupaten Tabanan, ketiga interaksi dengan Kabupaten Badung, keempat interaksi dengan Kabupaten Gianyar, kelima interaksi dengan Kabupaten Bangli, keenam interaksi dengan Kabupaten Buleleng, ketujuh interaksi dengan Kabupaten Karangasem, dan kedelapan interaksi dengan Kabupaten Jembrana. Keterkaitan dengan Kota Denpasar ini paling besar karena kedua daerah tersebut mempunyai jarak yang cukup dekat sehingga interaksi keduanya paling kuat. Interaksi dengan daerah ini dipengaruhi oleh jumlah penduduk dan jarak antara kedua daerah.

Ningsih (2010) melakukan studi tentang Analisis Komoditi Unggulan Sektor Pertanian Kabupaten Sukoharjo Sebelum dan Selama Otonomi Daerah dengan menggunakan alat analisis Location Quotient (LQ). Hasil studi menunjukkan pada masa sebelum otonomi daerah dapat diketahui komoditi yang teridentifikasi sebagai komoditi basis yaitu subsektor tanaman bahan makanan dan subsektor peternakan. Sedangkan selama pelaksanaan otonomi daerah, komoditi yang teridentifikasi sebagai komoditi basis yaitu subsektor tanaman bahan makanan, subsektor perkebunan dan subsektor peternakan.

\section{METODE PENELITIAN}

Data yang digunakan dalam penelitian ini adalah data sekunder yaitu time series berupa data Produk Domestik Regional Bruto di Kabupaten Dairi dan Provinsi Sumatera Utara selama lima tahun yaitu 2009 - 2013.

Daerah penelitian dipilih secara sengaja (purposive) yaitu Kabupaten Dairi dengan pertimbangan masyarakat di Kabupaten Dairi pada umumnya sebagian besar bermata pencaharian di sektor pertanian.

Untuk menganalisis sektor basis/unggulan digunakan Location Quotion (LQ) yaitu perbandingan relatif antara kemampuan suatu sektor di daerah yang diselidiki dengan kemampuan yang sama pada daerah yang lebih atasnya dengan rumus:

$$
\mathrm{LQ}=\frac{\text { PDRB sektoral kabupaten/Total PDRB kabupaten }}{\mathrm{PDRB} \text { sektoral provinsi/Total PDRB provinsi }}
$$

QE Journal | Vol.04 - No.02 June 2015 - 116 
Dengan kriteria :

- LQ lebih besar dari satu (LQ > 1), berarti komoditas tersebut merupakan sektor basis, artinya produksi komoditas yang bersangkutan sudah melebihi kebutuhan konsumsi di daerah dimana komoditas tersebut dihasilkan dan kelebihannya dapat dijual ke luar daerah. Dalam hal ini tingkat spesialisasi sektor tertentu pada kabupaten i lebih besar dari sektor yang sama pada tingkat provinsi.

- LQ lebih kecil dari satu (LQ $<1)$, berarti produksi komoditas tersebut belum mencukupi kebutuhan konsumsi di daerah yang bersangkutan dan pemenuhannya didatangkan dari daerah lain. Dalam hal ini spesialisasi sektor tertentu pada kabupaten i lebih kecil dari sektor yang sama padatingkat provinsi.

- LQ sama dengan satu $(\mathrm{LQ}=1)$, berarti produksi komoditas yang bersangkutan hanya cukup untuk kebutuhan daerah setempat. Dalam hal ini tingkat spesialisasi sektor tertentu pada kabupaten i sama dengan sektor yangsama pada tingkat provinsi.

Untuk menganalisis kontribusi sektor pertanian terhadap Produk Domestik Regional Bruto digunakan rumus:

$$
\mathrm{Ks}=\frac{\text { PDRBs }}{\text { PDRBt }} \times 100 \%
$$

Dimana,

Ksp : Besarnya kontribusi Sektor Pertanian pada tahun ke-t (\%)

PDRBp : PDRBp sektor pertanian pada tahun ke-t (rupiah)

PDRBt : Total Produk Domestik Regional Bruto (rupiah)

\section{HASIL DAN PEMBAHASAN}

\section{Sektor Basis atau Unggulan dalam Perekonomian Kabupaten Dairi}

Analisis Location Quotient (LQ) digunakan untuk menganalisis sektorsektor ekonomi yang termasuk ke dalam sektor basis atau unggulan atau berpotensi ekspor dan sektor non basis. Apabila hasil perhitungannya menunjukkan angka lebih dari satu $(\mathrm{LQ}>1)$ berarti sektor tersebut merupakan sektor basis atau unggulan. Sebaliknya apabila hasilnya menunjukkan angka kurang dari satu $(\mathrm{LQ}<1)$ berarti sektor non basis atau non unggulan. 
Tabel 1. Nilai Location Quotient (LQ) di Kabupaten Dairi Tahun 2009 2013

\begin{tabular}{llrrrrr}
\hline \multirow{2}{*}{ No } & \multicolumn{1}{c}{ Sektor } & \multicolumn{7}{c}{ T a h u n } \\
\cline { 3 - 7 } & & $\mathbf{2 0 0 9}$ & $\mathbf{2 0 1 0}$ & $\mathbf{2 0 1 1}$ & $\mathbf{2 0 1 2}$ & $\mathbf{2 0 1 3}$ \\
\hline 1 & Pertanian & 2,64 & 2,63 & 2,65 & 2,71 & 2,74 \\
2 & Pertambangan dan Penggalian & 0,06 & 0,06 & 0,06 & 0,07 & 0,07 \\
3 & Industri Pengolahan & 0,02 & 0,02 & 0,02 & 0,02 & 0,02 \\
4 & Listrik, Gas dan Air Bersih & 0,37 & 0,37 & 0,36 & 0,37 & 0,39 \\
5 & Bangunan & 0,68 & 0,66 & 0,65 & 0,61 & 0,58 \\
6 & Perdagangan, Hotel dan Restoran & 0,81 & 0,81 & 0,80 & 0,80 & 0,79 \\
7 & Pengangkutan dan Komunikasi & 0,64 & 0,62 & 0,61 & 0,61 & 0,60 \\
8 & Keuangan, Persewaan dan Jasa & 0,27 & 0,28 & 0,27 & 0,25 & 0,25 \\
& Perusahaan & 1,09 & 1,10 & 1,15 & 1,17 & 1,20 \\
\hline
\end{tabular}

Sumber : Hasil Pengolahan Data, 2015

Berdasarkan Tabel 1 di atas, secara keseluruhan sektor basis atau memiliki peran yang tinggi sejak tahun 2009 - 2013 adalah sektor Pertanian dan Jasajasa. Hal ini ditandai dengan nilai LQ yang lebih besar dari satu.

Sedangkan sektor lainnya merupakan sektor non basis, yaitu : sektor Pertambangan dan Penggalian, Industri Pengolahan, Listrik, Gas dan Air Bersih, Bangunan, Perdagangan, Hotel dan Restoran, Pengangkutan dan Komunikasi, Keuangan, dan Persewaan dan Jasa Perusahaan karena memiliki nilai LQ lebih kecil dari satu.

\section{Kontribusi Sektor Pertanian Terhadap Produk Domestik Regional Bruto}

Melalui PDRB dapat diketahui kinerja ekonomi, pertumbuhan ekonomi, struktur ekonomi dan PDRB per kapita suatu daerah. Peranan setiap sektor dalam menghasilkan PDRB merupakan hal yang paling penting untuk melihat gambaran perekonomian daerah dan menjadi bahan perencanaan dalam menentukan arah pembangunan di masa yang akan datang.

Besaran PDRB Atas Dasar Harga Berlaku berfungsi untuk menggambarkan perubahan volume/kuantum produksi yang dihasilkan dan tingkat perubahan harga dari masing-masing kegiatan, sedangkan besaran PDRB Atas Dasar Harga Konstan berguna untuk melihat laju pertumbuhan perekonomian secara keseluruhan. Selanjutnya, perkembangan nilai PDRB Kabupaten Dairi dapat diuraikan pada tabel dibawah ini. 
Tabel 2. Produk Domestik Regional Bruto Kabupaten Dairi Menurut Lapangan Usaha Atas Dasar Harga Berlaku Tahun 2009 - 2013 (Jutaan Rupiah)

\begin{tabular}{|c|c|c|c|c|c|c|}
\hline \multirow{2}{*}{ No } & \multirow{2}{*}{ Sektor } & \multicolumn{5}{|c|}{ Tahun } \\
\hline & & 2009 & 2010 & 2011 & 2012 & 2013 \\
\hline 1 & Pertanian & 205959815 & 227718552 & 251853044 & 280206311 & 312533753 \\
\hline 2 & $\begin{array}{l}\text { Pertambangan dan } \\
\text { Penggalian }\end{array}$ & 276725 & 310684 & 354517 & 408466 & 476931 \\
\hline 3 & Industri Pengolahan & 1346209 & 1466480 & 1592827 & 1735429 & 1906420 \\
\hline 4 & $\begin{array}{l}\text { Listrik, Gas dan Air } \\
\text { Bersih }\end{array}$ & 1245901 & 1327199 & 1444887 & 1591238 & 1753853 \\
\hline 5 & Bangunan & 14496993 & 15849816 & 17747776 & 19499888 & 21541200 \\
\hline 6 & $\begin{array}{l}\text { Perdagangan, Hotel } \\
\text { dan Restoran }\end{array}$ & 52066228 & 57953872 & 64582935 & 72031470 & 81355684 \\
\hline 7 & $\begin{array}{l}\text { Pengangkutan dan } \\
\text { Komunikasi }\end{array}$ & 19221176 & 21196506 & 23907204 & 27197355 & 30788599 \\
\hline 8 & $\begin{array}{l}\text { Keuangan, Persewaan } \\
\text { dan Jasa Perusahaan }\end{array}$ & 6120730 & 7041516 & 7935867 & 9069062 & 10238911 \\
\hline 9 & Jasa-jasa & 38565922 & 44909391 & 53209188 & 61403225 & 73946207 \\
\hline & PDRB & 339299700 & 377774016 & 422628245 & 473142445 & 534541557 \\
\hline
\end{tabular}

Sumber : Badan Pusat Statistik Kabupaten Pakpak Bharat, 2014

Berdasarkan Tabel 2, pada tahun 2009 - 2013 PDRB Kabupaten Dairi atas dasar harga berlaku mengalami kenaikan, dimana pada tahun 2013 PDRB Kabupaten Dairi mencapai Rp. 534541557 juta. Nilai PDRB ini dikontribusi oleh sektor pertanian yang terbesar yaitu Rp. 312533753 juta, dan yang terkecil oleh sektor pertambangan dan penggalian yaitu sebesar Rp. 476931 juta.

Berdasarkan Tabel 3, sektor pertanian masih mendominasi struktur PDRB di Kabupaten Dairi. Kontribusi sektoral terhadap Produk Domestik Regional Bruto Kabupaten Dairi Menurut Lapangan Usaha Atas Dasar Harga Berlaku pada tahun 2009 - 2013 didominasi oleh sektor pertanian, yaitu sebesar 60,701 persen untuk tahun 2009, sebesar 60,279 persen untuk tahun 2010, sebesar 59,592 persen untuk tahun 2011, sebesar 59,222 persen untuk tahun 2012 dan sebesar 58,468 persen untuk tahun 2013. 
Tabel 3. Kontribusi Sektoral Terhadap Produk Domestik Regional Bruto Kabupaten Dairi Menurut Lapangan Usaha Atas Dasar Harga Berlaku Tahun 2009 - 2013 (Persen)

\begin{tabular}{|c|c|c|c|c|c|c|}
\hline \multirow{2}{*}{ No } & \multirow{2}{*}{ Sektor } & \multicolumn{5}{|c|}{ Tahun } \\
\hline & & 2009 & 2010 & 2011 & 2012 & 2013 \\
\hline 1 & Pertanian & 60,701 & 60,279 & 59,592 & 59,222 & 58,468 \\
\hline 2 & $\begin{array}{l}\text { Pertambangan dan } \\
\text { Penggalian }\end{array}$ & 0,082 & 0,082 & 0,084 & 0,086 & 0,089 \\
\hline 3 & Industri Pengolahan & 0,397 & 0,388 & 0,377 & 0,367 & 0,357 \\
\hline 4 & Listrik, Gas dan Air Bersih & 0,367 & 0,351 & 0,342 & 0,336 & 0,328 \\
\hline 5 & Bangunan & 4,273 & 4,196 & 4,199 & 4,121 & 4,030 \\
\hline 6 & $\begin{array}{l}\text { Perdagangan, Hotel dan } \\
\text { Restoran }\end{array}$ & 15,345 & 15,341 & 15,281 & 15,224 & 15,220 \\
\hline 7 & $\begin{array}{l}\text { Pengangkutan dan } \\
\text { Komunikasi }\end{array}$ & 5,665 & 5,611 & 5,657 & 5,748 & 5,760 \\
\hline 8 & $\begin{array}{l}\text { Keuangan, Persewaan dan } \\
\text { Jasa Perusahaan }\end{array}$ & 1,804 & 1,864 & 1,878 & 1,917 & 1,915 \\
\hline 9 & Jasa-jasa & 11,366 & 11,888 & 12,590 & 12,978 & 13,834 \\
\hline & PDR B & 100,00 & 100,00 & 100,00 & 100,00 & 100,00 \\
\hline
\end{tabular}

Sumber : Hasil Pengolahan Data, 2015

Pada tahun 2013 sektor pertanian masih menjadi sektor utama pendukung perekonomian di Kabupaten Dairi, seperti tanaman kopi, kakao, jeruk, jagung dan komoditi lainnya masih menjadi komoditas andalan. Sesuai dengan harapan Pemerintah Daerah untuk menjadikan Kabupaten Dairi sebagai penghasil tanaman pangan dan perkebunan. Sedangkan sektor yang menjadi penyumbang terkecil untuk nilai PDRB Kabupaten Dairi pada tahun 2009 - 2013 adalah sektor pertambangan dan penggalian yaitu sebesar 0,089 persen.

\section{SIMPULAN DAN SARAN}

\section{Kesimpulan}

Berdasarkan hasil penelitian dan pembahasan yang telah diuraikan, maka dapat disimpulkan sebagai berikut: (1) Sektor pertanian dan jasa-jasa merupakan sektor basis atau memiliki peran yang tinggi dalam suatu perekonomian, hal ini ditandai dengan nilai LQ yang lebih besar dari satu; (2) Sejak tahun 2009 - 2013 sektor pertanian memberikan kontribusi terbesar dalam struktur PDRB di Kabupaten Dairi. 


\section{Saran}

Berdasarkan pembahasan dan kesimpulan maka dapat disarankan adalah sebagai berikut: (1) Kepada pemerintah agar lebih memperhatikan sektor pertanian karena sebagian besar penduduknya menggantungkan hidupnya pada sektor tersebut; (2) Perlu adanya pengolahan bahan baku dari sektor pertanian lebih lanjut, seperti pengolahan biji kopi, kakao dalam rangka meingkatkan nilai tambah dari paroduk olahan tersebut.

\section{DAFTAR PUSTAKA}

Arsyad, L, 1999. Pengantar Perencanaan dan Pembangunan Ekonomi Daerah. BPFE UGM. Yogyakarta.

Badan Pusat Statistik, 2014. Pakpak Bharat Dalam Angka 2014. Kabupaten Pakpak Bharat, Salak.

Ningsih, E.S.M. 2010. Analisis Komoditi Unggulan Sektor Pertanian Kabupaten Sukoharjo Sebelum dan Selama Otonomi Daerah. Tesis Universitas Sebelas Maret, Surakarta.

Nurfatimah, A. 2013. Analisis Potensi Pertumbuhan Ekonomi Kabupaten/Kota di Provinsi Bali. Skripsi UIN Syarif Hidayatullah, Jakarta.

Richardson, H. 1978.Dasar Dasar Ekonomi Regional. Lembaga Penerbit Fakultas Ekonomi Universitas Indonesia, Jakarta.

Sjafrizal. 2008. Ekonomi Regional, Teori dan Aplikasi. Baduose Media Cetakan Pertama, Padang.

Tarigan, R. 2005. Perencanaan Pembangunan Wilayah. Bumi Aksara, Jakarta.

Todaro, M.P. 2000. Pembangunan Ekonomi di Dunia Ketiga Edisi Ketujuh. Jilid Satu, Diterjemahkan Oleh Munandar, Erlangga, Jakarta.

Tambunan, T.T.H. 2001. Perekonomian Indonesia: Teori dan Temuan Empiris. Ghalia Indonesia. Jakarta. 